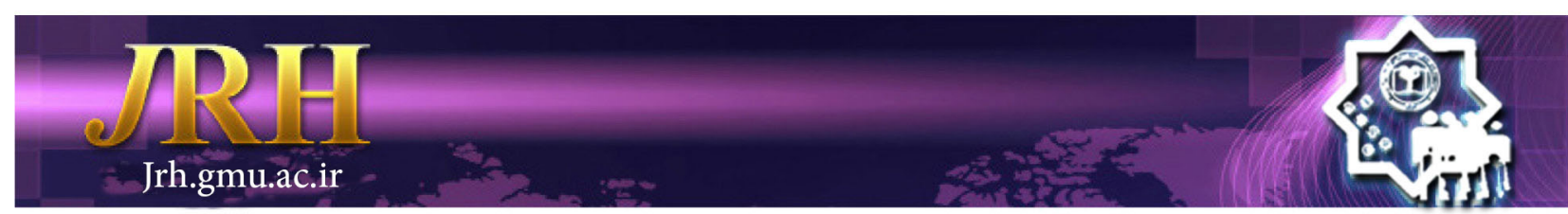

\title{
Relationship between internet addiction and dependency virtual social networks with loneliness in adolescents
}

Bibi Aghdas Asghari ${ }^{1}$

\section{Journal of Research \& Health \\ Social Development \& Health Promotion Research Center \\ Vol. 8, No.5, Sep \& Oct 2018 \\ Pages: 442- 450 \\ DOI: 10.29252/jrh.8.5.442 \\ Original Article}

1. Correspondence to: Department. of Social Science, School of Humanities, Islamic Azad University Gonabad Branch, Gonabad, Iran

Email: a_asghari2002@yahoo.com

Received: 29 Apr 2017

Accepted: 29 Apr 2018

How to cite this article: Asghari BA. Relationship between internet addiction and dependency virtual social networks with loneliness in adolescents. $J$ Research \& Health2018; 8(5): 442- 450.

\begin{abstract}
The prevalence rate of harmful use of cyberspace in the world is constantly increasing. This means that those who are addicted to the Internet, experience negative consequences of it, such as feeling of loneliness and isolation, and a vicious circle as well as a bilateral relationship may be involved. In this paper we studied the relationship between online social network dependency and internet addiction with loneliness in Gonabad adolescents. The statistical population consisted of all adolescents in the range of 13-20 years in Gonabad city. Samples have been selected just among high school students because of the easy accessibility. The participants includes 568 boys and girls students in 9, 10 and 11 grades of high school. Three questionnaires were the Internet Addiction Test (IAT), University of California, Los Angeles Loneliness Scale and researcher-made questionnaire of virtual social network dependency. The results showed that the rate of intense addiction to internet among Gonabadian adolescents $(8.8 \%)$ is lower compared to the prevalence of internet addiction among Iranian adolescents (10.24\%). Also the mean of loneliness is nearly 40 and $16.9 \%$ (98 individuals) of the participants have earned scores higher than the mean of loneliness and $83.1 \%$ of adolescents had score lower than the mean of loneliness. Data shows that there is very weak direct and significant statistical relationship between internet addiction and loneliness and between virtual social network dependency and loneliness. The results showed that but adolescents did not feel emotional loneliness and severe social isolation despite the dependence on modern media tool is elusive from society and need for privacy (away from other people).
\end{abstract}

Keywords: Dependency, Loneliness, Media, Virtual Social Network

\section{Introduction}

Iran is a young country in which more than half of the population is under 18 years of age. According to the 2016, the population of 15-19 year-old adolescents in all over the country is 6607043 and in Gonabad had 14692 individuals between 15-21 years old. It is obvious that each country's future depends on the health of its children and adolescents. Whiles about onefifth of the world's children and adolescents are suffering from psychological disorders in mild to severe level. [1] The students' mental health assessment is one of the major issues of improving mental health in society. Since adolescence is one of the most critical periods of life and students meet stressful issues of adolescence so they are likely to be prone to emotional problems. [2]. Currently about 694 million people over 15 years old in the world 
use Internet so that this figure is $14 \%$ of the total people over 15 years old. According to a survey conducted by the Onet On-line Institute, 75 percent of young people between 16-24 year-old feel that they cannot live without the Internet. [3] The use of the Internet has had a rapid rise in Iran and its users are increasing day by day. According to statistics, the numbers of Iranian users of the Internet in 2006 were 11 million that was reached to 33 million and 200 thousand people in 2010 and thus Iran has won the first place in the Middle East [4].

The prevalence of harmful use of cyberspace in Iran has been reported between 8.3 to $86 \%$ of internet users. The prevalence rate of harmful use of cyberspace in the world has been estimated $6-80 \%$. [5] This change may cause a feeling of loneliness. This means that those who are addicted to the Internet experience its negative consequences such as feeling of loneliness and isolation and a vicious circle as well as bilateral relationship may be involved so this means that people with lonely feeling use virtual social networks to reduce the pressure of loneliness and thus their loneliness would be increased. Although its social usage is one of the important usages but due to the fact which internet communication have less power compared to face to face relationships so that the excessive use of virtual social networks make people more alone finally [6]. Esen and colleagues [7] found there is significant relationship between using Internet and the rate of loneliness while they did not observe any relationship with the social self-efficacy. Some researches were conducted about internet dependency in Asia; Taiwan (Chiu-Hong) [8] Korea [9], Hong Kong (Chocó yo) [10]. The results of some abroad studies showed that mobile dependency and its extreme use has negative psychological effects on students [11]. Khazaie and colleagues found that there is a relationship between excessive and problematic use of cell phone and aggression and smoking, suicidal tendencies, low selfesteem, isolation and loneliness [5].

The study of Tan and colleagues [12] indicated that the rate of feeling loneliness in boy students is more than that in girl students. Also they have found a statistically significant relationship between the university students' loneliness feeling and the time of daily use of mobile. Students who have used daily 10 hours or less (1-3, 4-6 and 7-9 hours use mobile) felt more loneliness compare to students who have used less than one hour a day. Based on data analysis, $6.17 \%$ of students participating in the study were addicted to mobile phones. Also a statistically significant relationship was found between students' feeling of loneliness and mobile dependency; therefore the students' score who were addicted to mobile phones were higher than the students who were not addicted. People in situation can be supported to receive individual or group counseling assistances in order to use technological tools as their needs. Zarbakhsh Bahri and colleagues [13] concluded that feeling of loneliness and two subscales include emotional symptoms and relationships with family have positive and significant correlation with Internet dependency.

Social psychologists have given various definitions for loneliness phenomenon. Despite the variation in the definition of loneliness, Perelman and Pla mentioned four characteristics about loneliness which researchers agree on them: 1) feeling of loneliness is associated with some impairment in social relationships. 2) At least a part of it is subjective and related to expectations and perceptions of a person. 3) It is considered to be an unpleasant phenomenon. 4) People who feel loneliness become excited to lessen its intensity. Accordingly Bublé suggests that feeling of loneliness is "persuasion-intimacy" mechanism that has evolutionary origin and survival value for human species. The important point about the feeling of loneliness is that there is a lot of familiar and unfamiliar people surround the person but that person is not satisfied for any reason to communicate with them and they do not meet what the person expect in relationship with them. The person only has verbal communication with them but they do not fill own emotional and mental gaps and this condition occurs when 
the relationship does not meet expectations [14]. Loneliness is the gap between the aspirations of the person (what individual wants) and own achievements (what individual has earned) on interpersonal relationships and intimacies and this feeling is more in distance [15]. Two hypotheses are proposed to explain the relationship between feeling loneliness and using internet: First; the excessive use of the Internet leads to feel loneliness and the second is that lonely people tend more likely to use the Internet excessively [16] Cyberspace of internet social networking is one of the most important tools to appear of globalization effects. This cyberspace is a broad area of information and makes different semantic manifestations.

The person suffers from a suspension (meaning the tension and confusion) in facing with this space and plurality of resources in the construction of identity. The loss of time and place and the powerful role of space have a clear manifestation in the virtual world. People will see the foundations of their identity are shaking so they suffer from doubt and anxiety by facing with this second space. Although virtual social networks in the communication process can have positive and negative effects. The Internet is huge and complex network of millions of computers around the world that are linked together like a spider web. Since the internet present lots of positive and negative information, its potential risks are very disturbing especially for young generation. This growing concern about children and adolescents as passive recipients of media messages are innocent and defenseless victims of the media and like spell bounds and robots that they are subjected to a wide range of dependencies (from drug dependencies to Internet dependency, etc.). This will remind professionals of this field and families the need for more attention to this issue [17]. The numerous internet usages and its attractions have led to emerge a phenomenon known as "internet addiction" in recent years, as defined being dependency on internet is obsessive use of internet which is accompanied with measures such as isolation, depression, loneliness and anxiety [18].

Computers are only one way to access the Internet. Cell phones, smart phones, light handheld computers or tablets and other devices enable users to connect to the Internet from anywhere at any time. We live in a world where the use of mobile phones, especially among adolescents is strongly encouraged [19]. Use of the Internet and more recently especially virtual social networks among Iranians significantly increased and surveys indicate this trend still continues. It seems in the definition of internet dependency that quality of using the internet is more important than the quantity of it. In fact, some people work more than 20 hours per week with the Internet without any problem.

As Figure 1 shows, the effectiveness of dependence on of Internet and virtual networks on loneliness is conditional to the quality and quantity of use (such as the duration and type of networks) of these two tools.

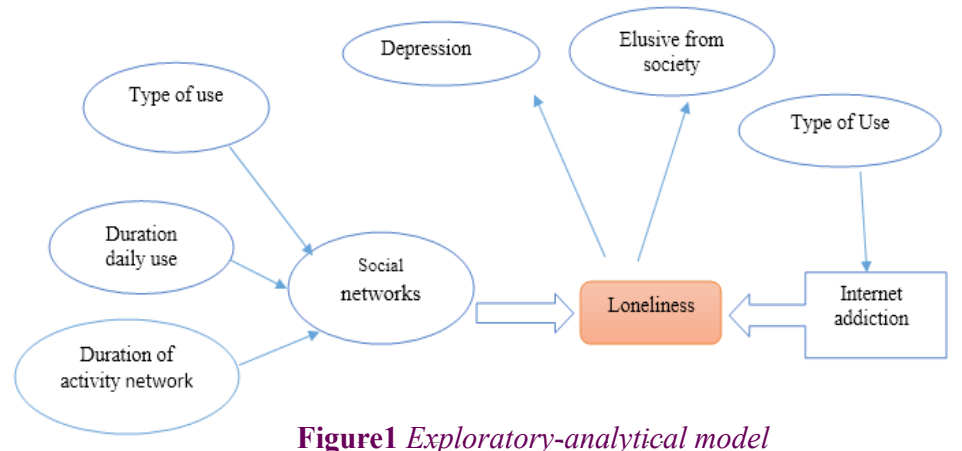

Figure1 Exploratory-analytical model

Therefore the main objective of paper is to determine the relationship between dependency to virtual social networks and internet addiction with loneliness in adolescents of Gonabad in 2016.

\section{Method}

The research is cross-sectional correlational study that was conducted among adolescents in Gonabad. The units of study in it are students 
of 9, 10 and 11 grade who enrolled in one of the boy or girl public or private high schools that had access to virtual social networks and the internet in Gonabad.

In the year 2016, the total number of adolescents in Gonabad city is 14692. Due to the easy accessibility to high school students, this group was selected as the target population. Girl and boy students of public and private high schools in Gonabad were 2256 that among them 1301 were girls and 995 was boy. The sample of the study (according to the Cochran's formula) included 568 boy and girl students in 9, 10 and 11 grades of high school. The sampling method in this study was multistage. The 71 people were selected based on the Cochran's formula.

Since in this paper, gender and type of school (public and private) is proposed so the sample size will be multiplied by 4 by using stratified sampling. $284=4 \times 71$

By using cluster sampling, a class was considered as a cluster, so by taking design effect $=2$, the sample size was determined $2 \times 284=568$.

First, the numbers of students who are supposed to be selected from public or private high schools were determined by dividing the number of public or private high school students on the total students then multiplied by the sample size (568). Then the number of classes which we should choose from each of these schools (public or private) was obtained by dividing this number to mean number of students per class and the number of girl and boy classes that we should select from public or private schools were determined by dividing the number of girl or boy classes to the total number of public or private classes was multiplied by the number of classes which we should choose from each of these schools (public or private).

The number of classes which should be selected among different grades has been determined by dividing these numbers by 3 (assuming parity of grades)and the required number of classes were selected among classes of each grade randomly. The instruments of this study are four questionnaires: the first one is demographic and background characteristics: demographic characteristics of person and his/her family and the quantity of using Internet and virtual social networks. The second one is Internet Addiction Test (IAT) which was developed by Kimberly Young in 1998. The test included 20 items in 5-point Likert scale from zero (never) to five (always). After response to all the questions, numbers would be added for each response to obtain a final score. The higher score shows the greater the level of addiction and the problems which Internet usage causes. The test has 20 items that each item includes 0-5 points. The total score is between 0 to 100 which is divided to 3 levels; normal users (20-49), mild dependence (50-79) and high dependency (80100). [20]

And the third one is the UCLA Loneliness Scale: It was used to assess loneliness which is the most known loneliness scale and almost has become the standard scale in this field. UCLA loneliness scale includes 20 questions that the reader should respond any of the questions on the Likert scale of 4 degrees that including never (1), rarely (2), sometimes (3) and often (4). The test scores range from 20 to 80 and a higher score indicates more loneliness. Therefore, the mean score is 50. Higher score than the mean score indicates greater intensity of loneliness. The loneliness feeling is when a person earns a score above the mean of 50 which is achieved by University of California, Los Angeles (UCLA) Loneliness Scale [16].

Finally the fourth questionnaire is dependency on virtual Social networks. Generally social networks in definition are sites that offer the sharing feature to their users from a simple site like search engine with added features such as chat and email and other features [21].

Dependence on virtual social networks (with reliability $\alpha=0.66$ ) were assessed by researcher made questionnaire which this questionnaire contains 30 items and each item of it has $0-5$ points. The total score is of 0 to 150 that is divided to 3 levels: normal user (50-79), mild addiction (80-119) and severe addiction (120150). Also, it is scored based on Likert scale of six options including never (1), rarely (2) sometimes (3) often (4), almost always (5) always (6) that high scores reflect excessive use. 
PartA of this questionnaire has been made available for consultation and the final questionnaire was set after applying comments and carrying out complementary reforms. For Alavi and colleagues [22] calculated Cronbach's alpha coefficient for the whole questionnaire $\alpha=0.88$, in a research called "the psychometric properties of the internet addiction test developed by Yang among students [23]. Bahirayi[24] and colleagues conducted a study entitled standardization of UCLA Loneliness Scale (version 3 ) in the community of students settled in Tehran; and found that UCLA scale with an average of 38.25 and standard deviation of 10.8 , have enough validity, reliability and internal consistency between Iranian students' samples.

For Part $\mathrm{C}$ of the questionnaire, Bahirayi and colleagues [24] conducted a study entitled as standardization of UCLA Loneliness Scale-3 among students of Tehran and found that UCLA scale with an mean of 38.25 and standard deviation of 10.8 have enough validity, reliability and internal consistency between Iranian students' samples.

\section{Results}

Results showed that the mean age of the adolescents in this study with the range of $13-20$ years was $( \pm 1.0216 .28)$. In terms of education and occupation of parents most of the mothers were housewives $(77.5 \%)$, or have a job unrelated to computer $(91.7 \%)$ or had diploma (54.2\%). Most fathers had Diploma (49.4\%) and many of them had jobs unrelated to computer (73.1\%). The mean number of close friends of adolescents with the range of 0-99 individual was $91.8 \pm 93.6$. The majority of the subjects of this study use their cell phone to log into cyberspace and virtual social networks (75.4\%). The highest percentage of samples use their cell phone to send text messages through social networks or chat $(31.7 \%)$, or use it to do works such as capturing and viewing photos and videos and listening to music $(25.8 \%)$ and connecting to the internet $(23.9 \%)$.

In the Table 1, the frequency distribution of the main variables is shown.

Table 1 Frequency distribution of dependence on Internet

\begin{tabular}{lccc}
\hline Internet addiction & Percentage & $\begin{array}{c}\text { Dependence on virtual } \\
\text { social networks }\end{array}$ & Percentage \\
\hline Normal user & 53.7 & low & 4.6 \\
Mild addiction & 37.5 & average & 77.6 \\
Extreme addiction & 8.8 & excessive & 17.7 \\
Total & 100 & Total & 100 \\
\hline Statistics & Total score of dependence & Total score of Internet & Total score of \\
& on social networks & addiction & loneliness \\
\hline Mean & 55.10 & 42.03 & 39.13 \\
Standard deviation & 19.86 & 18.22 & 411.46 \\
\hline
\end{tabular}

Table 2 The correlation between the total score of dependence on the Internet and virtual social networks and loneliness with individual and social variables

\begin{tabular}{lcccc}
\hline \multicolumn{1}{c}{ Spearman's correlation coefficient } & Total score of & $\begin{array}{c}\text { Total score of } \\
\text { lnternet addiction }\end{array}$ & $\begin{array}{c}\text { Total score of dependence } \\
\text { on virtual networks }\end{array}$ \\
\hline \multirow{2}{*}{ Age } & $\mathrm{r}$ & 0.095 & 0.219 & 0.228 \\
\hline \multirow{2}{*}{ Lonely hours daily } & $\mathrm{p}$ & 0.022 & 0.0001 & 0.0001 \\
\hline \multirow{2}{*}{ Number of close friends } & $\mathrm{r}$ & 0.060 & 0.069 & 0.153 \\
\hline \multirow{2}{*}{ Duration of mobile phone ownership } & $\mathrm{p}$ & 0.150 & 0.096 & 0.0001 \\
\hline Duration of record of activity in the & $\mathrm{r}$ & -0.164 & 0.189 & 0.204 \\
virtual social network & $\mathrm{p}$ & 0.0001 & 0.0001 & 0.0001 \\
\hline Hours of use of the virtual social & $\mathrm{r}$ & -0.040 & 0.194 & 0.130 \\
network daily & $\mathrm{p}$ & -0.333 & 0.0001 & 0.002 \\
\hline
\end{tabular}

Results of the hypotheses tests:

1) There is a relationship between the dependence on virtual social networks with adolescents' loneliness feeling (based on the background variables).

2) There is a relationship between the media 
dependency with adolescents' loneliness (based on background variables).

The following Table shows the results of hypotheses 1 and 2 tests.

Information of Table 2 indicates that there is a very weak direct but significant statistical relationship is between age and dependency to social networks $(p=0.0001, r=0.228)$, Internet dependency $(\mathrm{p}=0.0001, \mathrm{r}=0.219)$ and loneliness $(\mathrm{p}=0.022, \mathrm{r}=0.095)$. Other results are also available in the same Table.
The third hypothesis test:

3) There is a relationship between dependency on virtual networks with the media dependency in adolescents (based on background variables) of Gonabad.

In Table 3, using the chi-square test showed that there is significant relationship between the amount of using virtual social networks and Internet addiction. The results show these two variables have significant relationship and the third assumption is established.

Table 3 The frequency distribution of Internet dependency based on the use of virtual social networks

\begin{tabular}{lccccc}
\hline \multirow{2}{*}{$\begin{array}{c}\text { Dependence on virtual } \\
\text { networks }\end{array}$} & \multicolumn{3}{c}{ Internet addiction } & \multirow{2}{*}{ Sig. } \\
\cline { 3 - 5 } & Percentage & 7.4 & Mild & Normal user & \\
\hline Low & Perentane & 4.4 & 34.4 & 85.2 & \\
Medium & Percentage & 28.2 & 59.2 & 12.6 & 0.0001 \\
High & Percentage & 8.8 & 37.5 & 53.7 & \\
Total & Percentage & 8.9 & \\
\hline
\end{tabular}

Kruskal-Wallis test, Mann-Whitney $U$ test and Spearman's correlation coefficient were used to determine the significant relationship

between the level of internet addiction with the individual and social variables which their results were presented in Table 4.

Table 4 Total score of Internet addiction based on individual and social variables

\begin{tabular}{|c|c|c|c|c|c|c|c|}
\hline Variable & Options & Mean & $\mathrm{p}$ & Variable & Options & Mean & $\mathrm{p}$ \\
\hline \multirow{2}{*}{ Gender } & Girl & 38.99 & \multirow{2}{*}{0.001} & Checking & Not use & 41.05 & \multirow{2}{*}{0.002} \\
\hline & Boy & 45.55 & & E-mail & Use & 46.35 & \\
\hline \multirow{3}{*}{$\begin{array}{l}\text { Connecting to } \\
\text { the Internet with } \\
\text { mobile phones }\end{array}$} & Yes & 44.12 & \multirow{3}{*}{0.001} & \multirow{2}{*}{$\begin{array}{l}\text { Reading books } \\
\text { and journals }\end{array}$} & Not use & 43.06 & \multirow{2}{*}{0.002} \\
\hline & No & 34.96 & & & Use & 36.61 & \\
\hline & Not available & 38.33 & & \multirow{2}{*}{ Web browsing } & Not use & 48 & \multirow{2}{*}{0.012} \\
\hline \multirow{3}{*}{ Grade } & 9 & 37.66 & \multirow{3}{*}{0.001} & & Use & 41.34 & \\
\hline & 10 & 41.34 & & \multirow{2}{*}{$\begin{array}{l}\text { Virtual social } \\
\text { networks } \\
\text { Activity }\end{array}$} & Not use & 38.46 & \multirow{2}{*}{0.012} \\
\hline & 11 & 46.55 & & & Use & 48.36 & \\
\hline \multirow{5}{*}{ Field of Study } & Experimental Science & 41.24 & \multirow{5}{*}{0.001} & \multirow{2}{*}{ to chat } & Not use & 38.48 & \multirow{2}{*}{0.001} \\
\hline & Mathematics & 41.90 & & & Use & 49.77 & \\
\hline & Humanities & 45.32 & & \multirow{2}{*}{$\begin{array}{l}\text { Visiting } \\
\text { scientific sites }\end{array}$} & Not use & 43.96 & \multirow{2}{*}{0.001} \\
\hline & Technical Sciences & 48.04 & & & Use & 34.48 & \\
\hline & General & 37.66 & & \multirow{2}{*}{$\begin{array}{l}\text { Getting } \\
\text { information }\end{array}$} & Not use & 43.34 & \multirow{2}{*}{0.006} \\
\hline \multirow{5}{*}{$\begin{array}{l}\text { Most of mobile } \\
\text { phone use }\end{array}$} & Talking & 39.39 & \multirow{5}{*}{0.001} & & Use & 37.09 & \\
\hline & Internet connection & 51.50 & & \multirow{3}{*}{$\begin{array}{l}\text { Leisure Time } \\
\text { Activities }\end{array}$} & Alone & 45.29 & \multirow{3}{*}{0001} \\
\hline & Text messaging & 40.52 & & & $\begin{array}{c}\text { Along with } \\
\text { family members }\end{array}$ & 35.14 & \\
\hline & Game & 37.87 & & & $\begin{array}{l}\text { Along with } \\
\text { friends }\end{array}$ & 45.90 & \\
\hline & other & 37.36 & & & & & \\
\hline
\end{tabular}

Table 5 shows the relationship between participants and social variables with mean score of dependence on virtual social networks by using the Kruskal-Wallis (most cell phone use, grade, Leisure time activities), MannWhitney U (associating with the father's job, reading the newspaper and magazine and book, being present on social networks, chatting, visiting scientific sites, obtaining information, connecting to the internet with mobile phones) and Spearman correlation coefficient (father's education, grade, income).

The fourth hypothesis test:

4) There is a relationship between dependency on virtual social networks and media 
dependency with loneliness in adolescents of Gonabad (based on background variables)

According to the test, there is significant correlation between internet dependency and virtual social networks dependency and loneliness with background variables and there is a very weak direct and significant statistical relationship between age and social networks dependency $(\mathrm{r}=0.228, \quad \mathrm{p}=0.0001)$, internet dependency $(r=0.219, \mathrm{p}=0.0001)$ and feeling of loneliness $(\mathrm{r}=0.095, \mathrm{p}=0.022)$. There is a direct and significant statistical relationship between the number of close friends with virtual social network dependency $(\mathrm{r}=0.204$, $\mathrm{p}=0.0001)$ and internet dependency $(\mathrm{r}=0.189$, $\mathrm{p}=0.0001)$ and there is very weak inverse and significant statistical relationship with feeling of loneliness $(r=0.164, p=0.0001)$.

Table 5 The total score of dependence on virtual social networks based on social and individual variables

\begin{tabular}{|c|c|c|c|c|c|c|c|}
\hline Mean & Options & $\mathrm{p}$ & Mean & Variable & Options & $\mathrm{p}$ & Mean \\
\hline \multirow{2}{*}{$\begin{array}{l}\text { Communication } \\
\text { father's job with } \\
\text { computer }\end{array}$} & Yes & \multirow{2}{*}{0.018} & 52.28 & \multirow{4}{*}{$\begin{array}{l}\text { Father's } \\
\text { education }\end{array}$} & Illiterate & & 67.17 \\
\hline & No & & 56.14 & & Under Diploma & & 59.09 \\
\hline \multirow{5}{*}{$\begin{array}{l}\text { Most of mobile } \\
\text { phone use }\end{array}$} & Talking & \multirow{5}{*}{0.001} & 50.57 & & $\begin{array}{l}\text { High school } \\
\text { diploma }\end{array}$ & 0.002 & 55.30 \\
\hline & $\begin{array}{l}\text { Internet } \\
\text { connection }\end{array}$ & & 61.64 & & $\begin{array}{l}\text { University } \\
\text { education }\end{array}$ & & 51.25 \\
\hline & $\begin{array}{c}\text { Text } \\
\text { messaging }\end{array}$ & & 59.53 & \multirow{3}{*}{ Grade } & 9 & \multirow{3}{*}{0.001} & 49.55 \\
\hline & Game & & 48.74 & & 10 & & 56.41 \\
\hline & Other & & 47.25 & & 11 & & 58.06 \\
\hline \multirow{2}{*}{$\begin{array}{l}\text { Reading books and } \\
\text { journals }\end{array}$} & Use & \multirow[t]{2}{*}{0.001} & 56.50 & \multirow{5}{*}{$\begin{array}{l}\text { Field of } \\
\text { Study }\end{array}$} & $\begin{array}{l}\text { Experimental } \\
\text { Science }\end{array}$ & & 55.29 \\
\hline & Not use & & 47.66 & & Mathematics & & 55.34 \\
\hline \multirow{2}{*}{$\begin{array}{l}\text { Virtual social } \\
\text { networks Activity }\end{array}$} & Use & \multirow[b]{2}{*}{0.001} & 51.47 & & Humanities & 0.001 & 59.36 \\
\hline & Not use & & 61.52 & & $\begin{array}{l}\text { Technical } \\
\text { Sciences }\end{array}$ & & 59.81 \\
\hline \multirow[b]{2}{*}{ To chat } & Use & \multirow[b]{2}{*}{0.001} & 50.73 & & General & & 49.55 \\
\hline & Not use & & 64.61 & \multirow{3}{*}{$\begin{array}{l}\text { Family } \\
\text { income }\end{array}$} & $\begin{array}{l}\text { Less than } 500 \\
\text { thousand USD }\end{array}$ & & 59.24 \\
\hline \multirow{2}{*}{$\begin{array}{l}\text { Visiting scientific } \\
\text { sites }\end{array}$} & Use & \multirow{2}{*}{0.001} & 57.22 & & $\begin{array}{l}500 \text { thousand to } \\
1 \text { million }\end{array}$ & 0.004 & 56.49 \\
\hline & Not use & & 46.78 & & $\begin{array}{l}\text { More than } 1 \\
\text { million }\end{array}$ & & 52.15 \\
\hline \multirow[b]{2}{*}{ Getting information } & Use & & 57.36 & \multirow{4}{*}{$\begin{array}{l}\text { Leisure } \\
\text { Time } \\
\text { Activities }\end{array}$} & alone & & 53.72 \\
\hline & Not use & 0.001 & 46.51 & & $\begin{array}{c}\text { Along with } \\
\text { family members }\end{array}$ & 0.01 & 50.40 \\
\hline \multirow{2}{*}{$\begin{array}{l}\text { Connecting to } \\
\text { the Internet with } \\
\text { mobile phones }\end{array}$} & Yes & \multirow[t]{2}{*}{0.001} & 57.38 & & $\begin{array}{l}\text { Along with } \\
\text { friends }\end{array}$ & & 58.98 \\
\hline & No & & 46.75 & & & & \\
\hline
\end{tabular}

\section{Discussion}

The results of this study proved all three hypotheses "there is relationship between Internet addiction and adolescents' loneliness in Gonabad city" and "there is a relationship between dependence on virtual social networks with adolescents' loneliness in Gonabad" and " there is a relationship between dependence on virtual social networks with Internet dependency of adolescents in Gonabad".

The results showed that $37.5 \%$ of the samples were moderately addicted to the internet and
$8.8 \%$ had severe Internet addiction. Statistics of prevalence of Internet addiction has shown that on mean the proportion of Internet addicts is about 2 to 5 million per 50 million regular user, i.e., approximately 5 to $10 \%$ of Internet users are addicted to the Internet [18] and [9] the study of Lopez-Fernandes et al. [23] confirmed this claim. The Results of some of the studies in Iran such as Masoudnia and Akbari [25] also confirmed this. Fortunately statistics of severe addiction to Internet 
among adolescents of Gonabad (8.8\%) are lower compared to the prevalence of Internet addiction among Iranian young adults (10\% - 24\%). But the important matter is that more than $37.5 \%$ of the adolescents in this study are moderately addicted to the Internet and may be at risk of severe addiction to the Internet. One of the results showed that $77.6 \%$ of the samples are at risk of addiction and $17.7 \%$ are dependent on their mobile phone. The study results of LopezFernandes et al. ([26] Carbonell et al., [27] and Khazaie et al., [28] are similar to this result. One of the results shows that the mean of loneliness is around 40 and $16.9 \%$ of samples had scores higher than mean and $83.1 \%$ of adolescents had a score below the mean for loneliness. This result is consistent with findings of Ma ZW et al [29]; Shevlin et al [30]. Other results show a very weak direct and significant statistical relationship between internet addiction and feeling of loneliness and a very weak direct and significant statistical relationship between virtual social networks and feeling of loneliness. This result is consistent with findings of Pontez [31] and Koyuncu [32]. The results also showed that there is a moderate direct and significant statistical relationship between internet addiction and dependency on virtual social networks. This result is consistent with the results of Ezoe and colleagues [33]. Another result showed that the mean score of Internet addiction in boys is higher than in girls. The higher Internet addiction score in boy students can be due to less limitation and less supervision from parents or because boys have more skill to use the Internet and they have more tendencies to use it. The mean score of Internet addiction in students of grade 11 were higher compared to students in 9 and 10 grades. This was due to increase in educational and research needs of students in grade 11 so their further skill to use the internet because of further communicating with their peers make more intimacy with them. The mean score of dependence on virtual social network according to the father's educational level were statistically significant. This finding is consistent with the study of Abedini and colleagues [34]. Fathers' higher education may lead to their better performance in communicating with their children, hence these children may have less desire to use virtual social networks to bridge the communication gap therefore have coherent and reasonable planning for their life. Results also showed that there is weak direct and significant statistical relationship between the hours of Internet use throughout the day with dependency on virtual social networks. Solhi [1] also concluded to the same result. Certainly people who spend longer hours on the Internet are at more risk of Internet addiction.

\section{Conclusion}

The present study showed that adolescents did not feel emotional loneliness and severe social isolation despite the dependence on modern media tool is elusive from society and need for privacy (away from other people).

\section{Acknowledgements}

The author would like to state her appreciation of all the participants.

\section{Contribution}

Study design: BAA

Data collection and analysis: BAA

Manuscript preparation: BAA

\section{Conflict of Interest}

"The authors declare that they have nocompeting interests."

\section{Funding}

The authors received no financial support for the research, authorship and/or publication of this article.

\section{References}

1- Solhi M, Sadeghi A, Ruodbari M. The effect of group discussion education on mental healthpreventive behaviors in adolescence school girls. Journal of Research \& Health2012; 2(2): 247-56.

2- Sadeghian E, Kosha MM, Gorji S. The Study of Mental Health Status in High School Female Students in Hamadan City. Scientific Journal of Hamadan University of Medical Sciences and Health Services2010; 17(3): 39-45.

3- Shoeibi F. Internet addiction. Iran: Green E-book; 2013. 
4- Qasemi V, Malekahmadi H. Examining internet addiction among users in the cofee nets of Shahin Shahr. Communication Research2010; 17(64): 51-77.

5- Khazaie T, Saadatjoo A, Dormohamadi S, Soleimani M, Toosinia M, Mullah Hassan Zadeh F. Prevalence of mobile dependency and adolescence aggression. Journal of Birjand University of Medical Sciences2013; 19(4): 430-8. 6- Mohseni Tabrizi A, Hoveyda L, Omidi F. Deep involving on cyber space and personal and psychological consequences: survey of young severs in Tehran city. Journal of Social Sciences2010; 4(3): 51-69.

7- Esen BK, Aktas E, Tuncer I. An analysis of university Students' Internet Use in Relation to Loneliness and social self-efficacy. Procedia Soc Behav Sci2013; 84: 1504-8.

8- Chiu SI, Hong FY, Chiu SL. An analysis on the correlation and gender difference between college students' internet addiction and mobile phone addiction in Taiwan. ISRN Addict2013; 2013:360607.

9- Wang L, Luo J, Bai Y, Kong J, Gao W, Sun X. Internet addiction of adolescents in China: Prevalence, predictors, and association with well-being. Addict Res Theor2013; 21: 62-9.

10- Yu L, Shek DT. Internet addiction in Hong Kong adolescents: a three-year longitudinal study. J Pediatr Adolesc Gynecol2013; 26 (3 Suppl): S10-7.

11- Jones T. Students' cell phone addiction and their opinions. The Elon Journal of Undergraduate Research in Communications2014; 5(1) 74-80.

12- Tan C, Pamuk M, Dönder A. Loneliness and mobile phone. Procedia Soc Behav Sci2013; 103: 606-11.

13- Zarbakhsh Bahri M, Rashedi V, Khademi M. Loneliness and internet addiction in students. Journal of Health Promotion Management2013; 2(1) :32-8.

14- Mohammadimajd D. Loneliness and totalitarianism. Tehran: Roshangaran and women's studies; 2008.

15- Tajvidi M, Zeighami Mohammadi S. The level of loneliness, hopelessness and self-esteem in major thalassemia adolescents. Scientific Journal of Iran Blood Transfuse Organ2012; 9(1): 36-43.

16- Salimi A, Jowkar B. Relationship between attachment understanding and personality predispositions with loneliness in adolescence. Journal of Psychology Achievements2012; 19(1): 245-64.

17- Bidi F, Kareshki H. The addiction to the internet (from perspective of the psychology). Tehran: Avayenoor; 2013. 18- Jafary N, Etemadi O, Asemi A. Family and media pathology computer and internet. Esfahan: Amokhteh; 2012. 19- Bahri N, Sadegh Moghadam L, Khodadost L, Mohammadzade J, Banafsheh E. Internet addiction status and its relation with students' general health at Gonabad medical university. Modern Care Journal (Scientific Quarterly of Birjand Nursing \& Midwifery Faculty)2011; 8(3): 166-73.

20-Dargahi H, Razavi S. Internet addiction and its related factors: a study of an Iranian population. Journal of the Iranian Institute for Health Sciences Research (Payesh)2007; 6(3): 265-72.

21- Pye, LW. Aspects of political development, Boston: little brown; 1966.

22- Alavi S, Eslami M, Maracy M, Najafi M, Jannatifard F, Rezapour H. Psychometric properties of young internet addiction test. Journal of Behavioral Sciences2010; 4(3): 183-89.

23- Lopez-Fernandez O, Honrubia-Serrano L, FreixaBlanxart M, Gibson W. Prevalence of problematic mobile phone use in British adolescents. Cyberpsychol Behav Soc Netw2014; 17(2): 91-8.

24- Bahirayi H, Delavar A, Abedi H. Standardization of UCLA loneliness scale (verion3) on students attending university in Tehran. Thought and Behavior in Clinical Psychology2005; 1(1): 6-18.

25- Masoudnia E. Problematic cyberspace use and risk of depression disorder incidence among adolescents in Yazd. Iranian Journal of Epidemiology2013; 8(4): 15-25. 26- Lopez-Fernandez O, Honrubia-Serrano M, Freixa-Blanxart M. Spanish adaptation of the" mobile phone problem use scale" for adolescent population. Adicciones2012; 24(2): 123-30.

27- Carbonell X, Chamarro A, Griffi ths M, Oberst U, Cladellas R, Talarn A. Problematic internet and cell phone use in spanish teenagers and young students. Anales de Psicología2012; 28: 789-96.

28- Khazaie T, Sharifzadeh G, Jahed Sarawani M, Khazaei T, Hedayati $H$. The relationship between emotional intelligence and mobile dependency of students in Birjand Azad University, 2012. Modern Care Journal (Scientific Quarterly of Birjand Nursing \& Midwifery Faculty)2014; 10(4): 279-87.

29- Ma ZW, Liang J-J, Zeng W-N, Jiang S, Liu T. The relationship between self-esteem and loneliness: does social anxiety matter? Int J Psychol Res2014; 6(2): 151-65. 30- Shevlin M, Murphy S, Mallett J, StringerM, Murphy J. Adolescent loneliness and psychiatric morbidity in Northern Ireland. Br J Clin Psychol2013; 52: 230-4.

31- Pontes HM, Griffiths MD, Patrão IM. Internet addiction and loneliness among children and adolescents in the education setting: an empirical pilot study. Aloma: Revista de Psicologia, Ciències de l'Educació $i$ de l'Esport2014; 32(1): 91-8.

32- Koyuncu T, Unsal A, Arslantas D. Assessment of internet addiction and loneliness in secondary and high school students. J Pak Med Assoc2014; 64(9): 998-1002. 33-Ezoe S, Toda M. Relationships of loneliness and mobile phone dependence with internet addiction in Japanese medical students. Open J Prev Med2013; 6(3): 407-12.

34- Abedini Y, Zamani B. Investigating motivation, type and rate of mobile use in university students. Contemporary Psychology2013; 7(2): 73-86.

\footnotetext{
Copyright@ 2016 ASP Ins. This open-access article is published under the terms of the Creative Commons Attribution-NonCommercial 4.0 International License which permits Share (copy and redistribute the material in any medium or format) and Adapt (remix, transform, and build upon the material) under the Attribution-NonCommercial terms.
} 